\title{
Ecological and Economic Components of Personnel Training for Minerals Processing Enterprises
}

\author{
Evgeny Zhernov ${ }^{1, *}$, and Evgenia Nekhoda $^{2}$ \\ ${ }^{1}$ T.F. Gorbachev Kuzbass State Technical University, Department of Economics, 650000 Kemerovo, \\ 28 Vesennyaya St., Russian Federation \\ ${ }^{2}$ National Research Tomsk State University, Department of Strategic Management and Marketing, \\ 634050 Tomsk, 36 Lenin Ave., Russian Federation
}

\begin{abstract}
In the paradigm of sustainable industrialization the problem of update of the content of vocational training of personnel for solid minerals mining and processing enterprises is considered in the study using the case of the ecological and economic component. The urgency of the problem is determined by the necessity to inculcate in future executives and specialists of these enterprises the paradigm of thinking appropriate to the nature conservation sustainable industrialization of the Kuzbass region rather than the primary goods periphery. In Russian regional policy the transfer of responsibility for the economy modernization to the regional level has attached the special importance to the ecological and economic training of specialists for the main real economy of the region. The article substantiates the reasonability, necessity and feasibility of the update of the ecological and economic component of the education of the students of the Mining Institute of T.F. Gorbachev Kuzbass State Technical University for the nature conservation sustainable industrialization of the mining region.
\end{abstract}

\section{Introduction}

The purpose of the study is to consider the problem of update of the content of vocational training of personnel for solid minerals mining and processing enterprises for the sake of educational support for the sustainable industrialization of the mining region using the case of the ecological and economic component. The scientific novelty of the study is in the development of the concept of education for the sustainable development of the Russian economy in relation to the mining region and the features of the current stage of its economic development, which is characterized by ignoring the requirement of balancing the natural and productive potentials of the territory. The scientific significance is in identification and systematization of the ecological and economic foundations of profile education for sustainable development of the Kemerovo region - a unique in its nature mining region of Western Siberia. The practical significance of the study is related to the possibilities to use the proposed measures for the justification, formulation and adoption of

*Corresponding author: zhee.eti@,kuzstu.ru 
solutions on the development of vocational mining education in the mining regions of the Russian Federation.

This goal is achieved by means of identification and scientific substantiation of the reasonability, necessity and feasibility of the update of the ecological and economic component of the vocational training of the personnel for solid minerals mining and processing enterprises in the interest of the nature conservation sustainable industrialization of the mining region, taking into account foreign experience. In the Kemerovo region training of the highly qualified personnel for solid minerals mining and processing enterprises has been carried out since 1950 in T.F. Gorbachev Kuzbass State Technical University. This training steadily includes an ecological and economic component. Today it contains such disciplines as ecology, noxology, ecological examination, resource-saving technologies, the history of ecological movement, management of technospheric security, mining ecology, rational use and conserving of natural resources, economic theory, economics, managerial economics, economics and management of mining, etc.

\section{Materials and Methods}

The conducted content analysis shows that the ecological and socio-economic aspects are not fully complete and are not systematically expressed in the syllabuses for these disciplines. Ecologization of economic education for students of the mining institute of all levels: bachelors, mining engineers (specialists), masters, researchers (hereinafter - miners) is a process objectively conditioned by the specifics of their future professional activity.

Lagging of economic science in the field of sustainable development is predetermined, from our point of view, by its commitment to the primary goods focus of Russia's industrial development. The root of the problem is that economic development, in the wake of technical and technological development, is based on the old mechanistic scientific paradigm that does not take into account the laws of the complex socio-ecological and economic systems of the mining region. The main cause of the current crisis of the system "nature - individual - society" is the management of the socio-economic system of the mining region not coordinated with the laws of nature. Such management is carried out by executives trained by the outdated education system. They had been taught to the traditional economics that does not consider the main practical issue of balancing the pace of economic development with the capabilities of natural systems. Meanwhile, the requirement to balance the production, economic and natural potentials of the territory is the most important condition for the transition to a new state of the regional economic system.

In our opinion, one of the most promising areas for the development of the regional economic system of the Kuzbass is the nature conservation sustainable industrialization (hereinafter - NCSI) of the extractive industry. The main imperatives of the NCSI are: radical change in the paradigm of regional economic development; determination of and adherence to the natural limits of development of industrial and economic activity; parity of nature and anthroposocial origin; harmonization of the human economy with the laws of the economy of nature; the productivity of natural resources and the diversity of the natural environment are the basis for the sustainability of the environment transformed by man and the development of society.

The relationship of this study with the previously published works. The economics of nature management as a scientific discipline at one time by different authors was called "The theory of environmental policy" [1], "Economics of natural resources and the environment" [2;3], "Environmental and natural resource economics" [4;5]. In this case W.J. Baumol and W.E. Oates in the second edition of their textbook [6] noted that it is devoted to the analysis of the economy of the environment (environmental economics). 
D.W. Pearce and R.K. Turner rightly warned against the opposition of economy and nature, calling for consideration of the ethical moments of the process of "mastering" nature. In that manner the natural resources that form the natural environment have been correctly included in the scientific and educational field of consideration, there has been a natural integration of the so-called resource economy as a complex of concrete economic disciplines that study certain natural resources from an economic point of view, with the economy of the natural environment.

In the late 1980s and early 1990s, ecological economics appeared [7-10]. One of the leaders of this school R. Costanza [11] defines the ecological economics as an interdisciplinary area of knowledge, studying the relationship between ecological and economic systems in the broadest sense, which is of paramount importance for the organization of a sustainable future.

In our study, the concepts of "ecological economics", "economics of nature management", "environmental and natural resource economics", we consider as synonymous, mutually complementary, covered by the more general concept of "economics of nature". Only the economics of nature - the expanded concept of the sciences listed above, aimed at preserving the natural conditions of life, has a common ideological platform - the all-round well-being of man - with the knowledge economy, which, in our opinion, should be developed in the 21 st century in all regions of the country, including resource-extracting ones. But, following the historical tradition, for educational purposes, one can use the concepts listed above.

On the basis of the concept of sustainable development [12], the theory of economy of sustainable development has emerged. This economy uses natural resources rationally and optimizes their transfer between generations. The economics of sustainable development includes urgent topics that are missing in modern economic theory, which link natural sciences and humanities. The latter is especially important in training miners to study the problem of the safe inclusion of the economics of man and the economics of knowledge in the economics of nature. In our opinion, this problem is conditioned by the fact that nature eliminates those anthroposocial elements that do not correspond to the laws of its development.

The economics of sustainable development corresponds to the concept of education for sustainable development. In accordance with this concept, education is the foundation of sustainable development, as described in chapter 36 of Agenda 21, adopted by the United Nations Conference on Environment and Development (Rio de Janeiro, 1992) [13]. In this context education is a tool for addressing such vital issues of regional development as ecology, biodiversity, natural resource management, sustainable production and consumption, public health care, human values and human rights. It is noteworthy that there is no universal model of education for sustainable development: the agreement of different countries and regions of one country with respect to the general concept does not limit individual approaches to education, conditioned by local peculiarities and priorities. Accordingly, each country and region of the country should determine their priorities, objectives and choose appropriate ways to achieve them, based on local ecological, social, economic conditions. For the production sector of the mining region, the priority is the extractive industry. In these circumstances its goal is to make the mining industry a sector with high added value worthy of the knowledge economy through fundamental structural and resource changes. Education for sustainable development is equally critical for both technologically developed and developing mining regions of the country.

The United Nations and UNESCO declared the Decade of Education for Sustainable Development the period 2005-2014 [14]. Today, the main contours of the new model of education are being formed, in which the economic, social, humanitarian and other areas of the educational process will be integrated into a single system. Russia's participation in this 
direction is envisaged [15]. It seems that this concerns first of all the Russian mining regions with their pronounced ecological and socio-economic problems.

\section{Results and Discussion}

Education for sustainable development is a dynamic concept that includes all aspects of training in order to ensure the interrelationship between sustainable development issues and the acquisition of relevant values, knowledge and skills by future executives and specialists. Its implementation will enable young people to voluntarily commit themselves to creating broad prospects for the nature conservation sustainable industrialization of the region and responsible ownership of them. Responsibility of the university for the future of the region is expressed in the training of such highly qualified personnel with a no narrowness worldview. Sustainable development requires a holistic approach: economic education for it is inextricably linked to other programmes s and training issues.

On this basis, the organization and methodology require the following: 1) development of guidelines for adopting a holistic interdisciplinary approach to education for the NCSI, integrating it into the existing educational system; 2) involvement of local universities and communities in the implementation and support of education programmes for sustainable industrialization; 3) improving training in the form of reorientation of university teachers to provide educational technologies for the NCSI of the region.

Economic education should take its rightful place along with ecological and geological education in the training of miners. To this end, the Department of Economics of T.F. Gorbachev Kuzbass State Technical University should refocus the syllabuses of the corresponding disciplines for the miners, making necessary changes in them in order to provide educational assistance to the nature conservation sustainable development. Economic theory is inseparably linked with other economic sciences and is now in the united field of the general scientific paradigm of economics, while nature management and environmental protection is the specialized sphere of the economy. Therefore, it seems logical to include the environmental economics and the ecological economics as sections (themes) in the syllabuses of the following disciplines: economic theory, economics, managerial economics. This proposal is due to the conclusions of the discussion between the representatives of the environmental economics and the ecological economics. The former consider environmental problems from the perspective of microeconomics and Pareto efficiency conditions. The latter focus on the inclusion of ecological indicators in macroeconomic indicators: the macroeconomics of human society should be included in the economics of the Earth's nature. Thus, for example, based on the structure of the discipline "Economics" (micro- and macroeconomics), it is necessary to pay attention to both approaches, not opposing them, but noting their positive aspects at different levels of the application. At the same time, in order to take into account the specifics of the Kuzbass, a quantitative analysis of natural and productive potentials at the regional level must be carefully considered.

We consider education as the initial element of the movement towards sustainable development, which provides people with the opportunity to translate into reality their understanding of society with its economy. Education not only gives scientific and technical knowledge, but also motivates, socially supporting the development of the required skills and their application in the real economy. It is only through education that one can help a person learn the values, nurture his attitude, behavior and lifestyle, necessary to ensure a sustainable future. Education for sustainable development is a learning process for how to make the decisions needed to ensure the long-term future of the economy, ecology and equality of all territorial communities. The development of thinking oriented to the correct harnessing of the world is a key task of training specialists for solid minerals 
mining and processing enterprises. At the same time, one must realize that the inhabitants of the region have their own sustainable character of the harnessing of the world associated with the ecological perception of the world. As a consequence of this connection, a stable economic structure of the population of the given territory develops. Coal mining has been the visiting card of the Kuzbass for many years. Therefore, the update of ecological and economic education in the interest of nature conservation sustainable industrialization of the mining region is expedient, in our view, to begin with the training of miners.

There is no need to prove to students who live in the Kuzbass that the mineral reserves are depleted, and the human habitat is destroyed through the pollution of the atmosphere, soil, water. Since birth they are witnesses of degradation of biota, depletion of nonrenewable fossil resources, overexploitation of the natural environment in the region. But at the same time, as future executives and specialists of the extractive industry, they must understand that the continued growth rates of fossil fuel production bring the danger of destruction of the ecosphere closer than the threat of exhaustion of resources. Although both have a negative impact on the quality of life of the current and future generations of the region's inhabitants. One should make clear for each student the words of the Declaration of the United Nations Conference on Environment and Development, held in Rio de Janeiro in 1992: "Human beings are at the centre of concerns for sustainable development. They are entitled to a healthy and productive life in harmony with nature" [13]. During their university training it is necessary to inculcate in future executives and specialists of solid minerals mining and processing enterprises of the region a new style of attitude to nature. The current systemic crisis of the regional economy is a convincing proof of the need for a transition to ecologically oriented growth in the real economy and the corresponding character of the training of its personnel.

The proposed measures are the results of the new vision of ecological and economic education that helps people of all ages to better understand the environment in which they live, to solve complex interrelated problems that pose a threat to their future - uneconomical consumption of natural resources, degradation of urban areas and the environment, health hazards, the violation of natural human rights. The new vision of education focuses on a holistic, interdisciplinary approach to developing the skills necessary to ensure a sustainable future, and also emphasizes the changing values, relationships and lifestyles. It requires a reorientation of the education system, its policies and practices to nature in order to empower the university graduate with the ability to make decisions and take appropriate actions to eliminate problems that pose a threat to the future development of the region. Thus, young people with an equally well-oriented education will develop views on the nature conservation sustainable industrialization alternative to mainstream economics and implement them in the real economy through creative cooperation for the benefit of the entire population of the region of residence.

\section{Conclusion}

The measures proposed in the study take into account foreign experience and update the ecological and economic component of the vocational training of personnel for solid minerals mining and processing enterprises. Our propositions are aimed at the educational support of the nature conservation sustainable industrialization. Ecological and economic literacy depends on understanding the goals and objectives of the nature conservation sustainable industrialization. It also includes the ability to identify the main causes of the emergence of threats to sustainable industrialization and find ways to eliminate them.

Specialists with good training in the field of ecologically and economically sustainable development will be most in demand by the real economy of the region in the new development process of the regional economic system. 


\section{Acknowledgements}

The research is done under the financial support of the Russian Foundation for Basic Research, Research Project No 18-010-00340 "Business Models of Companies as the Basis for the Formation of Common Values and Social Capital".

\section{References}

1. W. J. Baumol, W. E. Oates, The Theory of Environmental Policy: First edition (Prentice-Hall, New Jersey, 1975)

2. D. W. Pearce, R. K. Turner, Economics of Natural Resources and the Environment (Harvester Wheatsheaf, London, 1990)

3. E. Kula, Economics of Natural Resources and the Environment (Chapman \& Hall, London, 1992)

4. T. H. Tietenberg, Environmental and Natural Resource Economics (Scott, Foresman \& Company, Glenview, 1984)

5. T. H. Tietenberg, L. Lewis, Environmental and Natural Resource Economics (Routledge, New York, 2018)

6. W. J. Baumol, W. E. Oates, The Theory of Environmental Policy (Cambridge University Press, 1988)

7. R. Costanza, H.E. Daly, Ecol. Modelling, 38, 1 (1987)

8. R. Costanza, Ecol. Econ., 1, 1 (1989)

9. R. Costanza, Ecological Economics: The Science and Management of Sustainability (Columbia University Press, New York, 1991)

10. R. Costanza, O. Segura, J. Martinez-Alier, Getting Down To Earth: Practical Applications of Ecological Economics (Island Press, Washington, 1996)

11. R. Costanza, J. C. Cumberland, H. E. Daly, R. Goodland, R. Norgaard, An Introduction to Ecological Economics (St. Lucie Press, Boca Raton, 1997)

12. L.T. Brown, Building a Sustainable Society (W. W. Norton \& Co, New York, 1981)

13. Report of the United Nations Conference on Environment and Development, Rio de Janeiro, 3-14 June 1992, Vol. I. Resolutions Adopted by the Conference (United Nations, New York, 1993)

14. UNECE Strategy for Education for Sustainable Development (UNECE, Geneva, 2005).

15. Report on Implementation of the UNECE Strategy for Education for Sustainable Development within the framework of the United Nations Decade of Education for Sustainable Development (2005-2014) submitted by the Russian Federation (UNECE, Geneva, 2007) 